\title{
James Joyce's “An Encounter": From the Perversion of an Escape to the Perversion of the Fatherhood
}

\author{
Omid Ghahreman \\ English Literature PhD Candidate, Shiraz University \\ Eram Campus, Faculty of Humanities, Shiraz University, Shiraz, Iran \\ E-mail: ghahreman.omid@yahoo.com \\ Farideh Pourgiv (Corresponding author) \\ Professor of English Literature, Shiraz University \\ Eram Campus, Faculty of Humanities, Shiraz University, Shiraz, Iran \\ E-mail: fpourgiv@rose.shirazu.ac.ir
}

Received: 13-12- 2012

Accepted: 22-01- 2013

Published: 01-03- 2013

doi:10.7575/aiac.ijalel.v.2n.2p.158

URL: http://dx.doi.org/10.7575/aiac.ijalel.v.2n.2p.158

\begin{abstract}
Ambiguity is an indispensable part of modern fiction that has always implied what is always merited as the 'literariness' and 'sophistication' of that fiction. In modern fiction, particularly in James Joyce's Dubliners, ambiguity and indeterminacy transcend the textual difficulty and achieve a 'mysterious' level. That is to say, Joyce renders the frequent unfinished and elliptical sentences, as well as the absent words, phrases, paragraphs, and even characters more significant than all those present. In Dubliners, this unique concept of ambiguity and indeterminacy, that tends to be Joyce's narrative signature, is called "gnomonic" - a term derived from Euclid's gnomon. A gnomon is formed by removing a similar parallelogram from a corner of a larger parallelogram. Gnomons in Dubliners indicate not only the incompletion and failure, but also the dialectical cycle of presence and absence. Words prove mostly insufficient to convey meaning, and actions are subject to failure even before they start. But Joyce's approach to gnomon is not a passively confirming one. Joyce skillfully benefits the mysterious condition that his gnomonics make for sustaining his creativity in order to overwhelm intellectually the distorting powers in his society. Therefore, if Joyce's stories seem unsolvable and vague, it is not because of their merely textual difficulties. They present, instead, some gnomonic mysteries of varying degrees and depths. As a way to get readers to read Joyce thoughtfully, this study is going to shed light on this unique gnomonic nature of Joycean mysteries in "An Encounter", one of the childhood stories in Dubliners.
\end{abstract}

Keywords: Joyce, Dubliners, An Encounter, ambiguity, gnomon, paralysis

\section{Introduction}

Once writing about Dubliners (1914), David Daiches (1960) underlined that the narrative unity and the thematic coherence in this collection of stories owe so much to Joyce's special kind of pattern:

Joyce's realism in Dubliners is not therefore the casual observation of the stray photographer, nor is it the pilingup of unrelated details. All the stories are deliberately and carefully patterned, all have a density, a fullness of implication, which the even tone of the narrative by disguising [italics added] only renders more effective (31).

Joyce blends realistic details and symbols to form his pattern, and this pattern endorses many deliberately-designed blanks in both form and content of the stories in Dubliners. All this patterning with its complexity, vigor, and ambiguity represents Joyce's disguising art. And this art finally makes Joyce's stories mysteriously ambiguous. Joyce even does not hesitate to call himself openly an international figure of mystery. In a letter to Carlo Linati, Joyce calls Dubliners a mystery, while this mystery could not be accomplished without his mysterious craftsmanship:

The story of my books is very strange. I had to fight 10 years in order to publish Dubliners. The whole edition of 1000 copies was burnt by arson in Dublin: some said it was the work of the priests, some of my enemies, some of the Viceroy or of his wife the Countess of Aberdeen. It is in short a mystery. (qtd. in Bulson, 2006: 34)

This mystery, or as it is called ambiguity, is the focal point that surrounds the origin and development of Joyce's other works as well.

As a matter of fact, what we confront as 'ambiguous' or 'enigmatic' in stories of other modern writers, we should call 'gnomonic' in Joyce. Gnomonic, the true nature of Joyce's ambiguity, can be what Philip F. Herring (1987) justifiably discusses as Joyce's "uncertainty principle". In Joyce's stories, this uncertainty principle crystallizes the nature of Joyce's narrative and characterization where he tends to conceal rather than to reveal (Borg, 2010: 137). Herring believes, 
In Joyce's case we normally find that an essential piece of evidence is missing that would allow us a measure of security in interpretation; readers are invited to fill the gap by speculating about what is missing, such as what happened in an important scene omitted from a plot sequence. Uncertainty is to a great extent true of all literary texts, but it is untrue that authors before Joyce generally had uncertainty principles (P. xii).

Marian Eide (2004), however, sees the nature of this uncertainty very much similar to aporia: "the breakdown of immediate or accessible meaning". Whereas aporia signifies uncertainty and hopelessness in Beckett, for Joyce "the undermining of determinate meaning, the path that gives way, all of these are intellectual opportunities for creativity, for path breaking, for the entertaining of possibility from within the impossible. (P. 30).

Considerably, the absent words, phrases, sentences, paragraphs, and even characters are rendered more significant than all those present. Lee Spinks (2009) would rather see this principle as "the 'meanness' of Joyce's narrative" (50). Kain (1957) believes that "Joyce is a writer who must be heeded. This awareness deepens with each reading...[His writings] are that of a many-faceted prism, catching half-lights and projecting magnified distortions" (3). But that is not the climax yet; Joyce is a writer, continues Kain, whose incomparable joke was that he could be "the invisible man who was even able to make his invisibility invisible" (6). Joyce, the master of disguise, made an enormous effort to live and create an 'enigma' leaving behind puzzling blanks of various sizes and shapes for both readers and critics to recognize and fill. But what can really 'gnomonic' be, after all?

\section{Discussion}

As mentioned in Euclid's Book II of Elements, a gnomon is the part of a parallelogram which remains after a similar parallelogram has been taken away from one of its corners. The smaller parallelogram is considered to be the absently present form and its relation to the bigger-but-incomplete one endorses a symbolic, rather micro-macrocosmic, absence/presence pattern which has served Joyce to build a notional/functional foundation in his fiction (Simon 49). The following pictures clearly illustrate how a gnomon is formed:

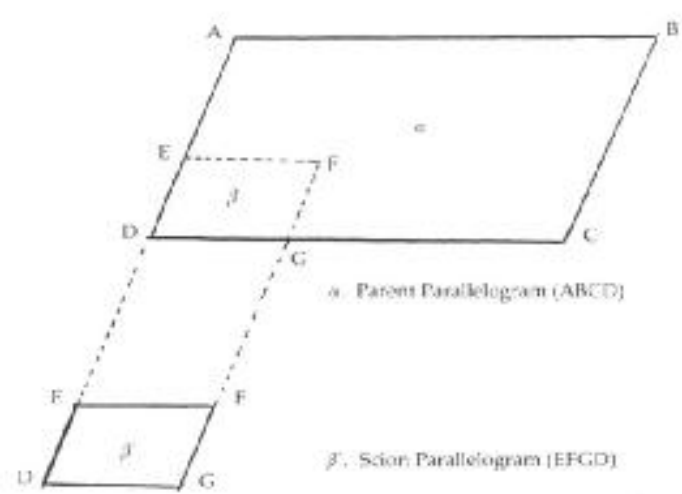

a. Picture (1)
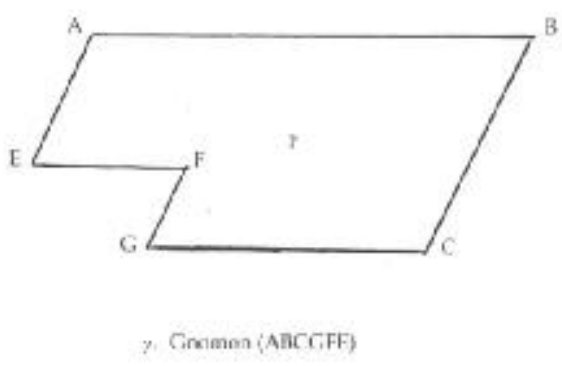

b. Picture (2)

Inasmuch as the gnomon is an incomplete parallelogram, this incompleteness leads meaningfully to the 'gnomonic existence' of Dubliners. To Joyce, the master of the words, the similarity between the words "parallelogram" and "paralysis" must have been remarkably noticeable. Dubliners, each a gnomon taken from the main parallelogram of Dublin, are all caught in the incomplete areas of human relationships. John Gordon (1995) sees even Joyce's country as a gnomon when he writes:

To make a gnomon, what you do is to take a rectangular piece of paper, crease it in half along width and length, then cut out one of the four smaller rectangles marked by the creases. (The map of modern-day Ireland, properly rendered, approximates such a figure.) A gnomon illustrates engineered absence, a sign of something subtracted. (online)

To put it into nutshell, a gnomon, according to Herring (1987), can be a "key synecdoche of absence, part of a political rhetoric of silence within a larger framework of language" (4). Being also the sign of absence, gnomons indicate imperfection, deficiency, and loss. The failings and fallings of 'no-men', their dislocations, their failure to communicate and belong make them potential gnomons in Dubliners. Gnomonic Dubliners mostly reveal the tragic-comic epiphanies 
of life-traps in which they are stuck; they are also doomed to be followed and surrounded by the shadows of the absent ones heading on in the universal marathon of the frustration - from the living to the dead.

Nonetheless, the etymology of the word "gnomon" reveals that what Joyce introduces as Euclid's gnomon is in fact the tip of an iceberg. "Gnomon" comes from the Greek meaning an "interpreter". An interpreter is someone who reveals and elaborates; someone who, like Joyce, casts lights at the end of each of his stories. Gnomon also means the "pointer on a sundial" which casts shadows though various in size but not in shape - like various gnomons different in size but similar in shape. Joyce's remarkable administration of the gnomonic play of light-dark must be taken into account here since the light-dark pattern has a major role in Dubliners. Gnomon can also be defined as a "carpenter's T-square" which indicates "creation" and "precision". Using his T-square gnomons, Joyce (1916) engraves his portrait as a largerthan-life creator who precisely "like the God of the creation, remains within or behind or beyond or above his handiwork, invisible, refined out of existence, indifferent, paring his fingernails" (A Portrait 358). The following study therefore, intends to give an analysis of Joyce's main principle of ambiguity in "An Encounter" demonstrating its distinctively gnomonic aspect of narrative and characterization.

"An Encounter" is the story of a young seeking boy whose romantic dreams and initial attempts for adventure lead him to nowhere but embitterment and disappointment. Priesthood (absent or present) still casts an inevitably unpleasant shadow over the lives of the youth inflicting them with frustration, disillusionment, and menace. We can find more clues to connect this story to "The Sisters". Thematically, we may consider them both archetypal. The former employs the image of the father though missed and lost; the latter employs the archetype of journey or quest. Interestingly, the image of the missing father resurfaces in "An Encounter" as Mahony asks "what would Father Butler be doing out at the Pigeon House" (Dubliners 14), while the idea of a bitter journey is already implied in "The Sisters" when the young protagonist accompanies his aunt to the dead priest's house filled with void and death.

The unnamed young protagonist in "An Encounter", like his counterpart in "The Sisters", is a small gnomon too: a loosened end of a Dubliner family. Whether he has a family or who his parents are is going to remain a dark point to the readers. We miss this information about his family as he himself seems to be missing his family physically and symbolically as well. That makes this young protagonist stay remarkably at a distance from his surroundings like a child gnomon detached from the parent parallelogram. Such a detachment, of course, sharpens his power of observation and fantasies: "when the restraining influence of the school was at a distance I began to hunger again for wild sensations, for the escape which those chronicles of disorder alone seemed to offer me" (Dubliners 14). He is also a gnomon/knowman seeking real adventures beyond the limiting borders of Dublin; he reads stories of the Wild West where he can imaginatively sneak through the "opened doors of escape" (Dubliners 13). After all, like almost all protagonists in Dubliners-except in "The Dead"-who move eastward to experience new life, adventure, or the future, the boy's destination is the Pigeon House, at Dublin's most easterly point.

Naturally, for those readers who have only read Dubliners or those who have no idea what a significant role "interrelatedness" and "continuity" play in Joyce's works, Joyce's insistence on presenting the young boy parentless and his emphasis on the boy's lack of sense of belonging may be puzzling and inconceivable, perhaps. In "An Encounter", one can say, Joyce introduces the gnomonic prototype of his artist, Stephen Dedalus, whose presence and thoughts will dominate his later major works.

This young story-teller provokes, too, a sense of mystery and skepticism by keeping us in the dark about his real age (and real feelings, perhaps). Apparently older than the young boy in "The Sisters", he attends school, reads American stories of the Wild West, takes part in some Indian battles arranged by his classmates, and, despite his young nature, tries to keep away from those childish conducts. It is clear that he does not fit in there feeling sick and tired of their foolish games. He sounds to be a seeker, a know-man/gnomon, who desires to walk away from his corner in the paralyzing life of Dublin.

Studying the nameless young more, we can discover a gnomonic portrait of Joyce's young artist, Stephen Dedalus, in him. He is interested in the adventures of the Wild West, but he likes "better some American detective stories which were traversed from time to time by unkempt fierce and beautiful girls" (Dubliners 13). The romantic mystery mirrored in the boy's thought evokes the similar one that will paint Stephen's childhood. Stephen's mind is occupied with romantic notions of escape and flight, while he dreams of the imaginative life of an adventurer and exile. We can take this, for instance, worthy of note when we find Stephen, too, concerned with revenge and love, some cliché motifs of detective stories: "His evenings were his own; and he pored over a ragged translation of The Count of Monte Cristo. The figure of that dark avenger stood forth in his mind for whatever he had heard or divined in childhood of the strange and terrible" (A Portrait 229). As it will be discussed later, Joyce does not hesitate to present some puzzling bits and pieces of premature Stephen's (or his) gnomonic portraits long before he is created to highlight the geometric design of his emerging immense universe.

More to the point, the young Stephen was only bodily on the playground of the school but hardly there at all distancing himself gradually from the familiar settings and people-be it his family and home or his friends and homeland. Even when he becomes ill at the school, he desires to get "better slowly", so that he could get himself a book and fly away on the wings of imagination to faraway lands: "There was a book in the library about Holland. There were lovely foreign names in it and pictures of strange looking cities and ships. It made you feel so happy" (A Portrait 198). Evidently, Stephen is warming up for his eventual vocation as an artist in exile, and, considering this fact, it is not difficult for the readers to recall the young boy in "An Encounter" as he feels almost the same desiring to be aboard sailing away abroad: 
The mimic warfare of the evening became at last as wearisome to me as the routine of the school in the morning because I wanted real adventures to happen to myself. But real adventures, I reflected, do not happen to people who remain at home: they must be sought abroad. (Dubliners 14)

How can someone, who believes the real adventures must be sought abroad, be just an inexperienced, simple-minded young boy? This gnomonic uncertainty about him is certainly rich to reconsider later on.

Although less enigmatic and elliptical than the opening story ("The Sisters"), "An Encounter" has its own mysterious twists and gnomonic moments for readers to challenge. The gnomonic number "three" covers the whole story as it refers to the three parts that include the main events as well as the number of the characters mainly involved. The first part is the young boy's introductory paragraphs about his playmates, some childish games, school, and teachers. The second part opens as he plans to escape the school with some classmates for a day in order to pay an entertaining visit to the Pigeon House. And the last, and the epiphanic, section is when the boys encounter the queer old man. But this adventurous journey is doomed to fail since the boys "must have at least three" (Dubliners 15), while, due to the absence of Leo Dillon, they are two beings more incomplete than a gnomon. All the joy, sunlight, and hope they have are going to fade away by Leo's failure to show: Leo's absence is the first omen that all will not go according to plan. "Two companions appear, one remains hidden; this void will be filled by another who will define the geometric shape of their adventure" (Herring, 1987: 21). Interestingly, the strange new-comer (the replaced third corner) intensifies the sense of loss, absence, and gap himself since the young boy notices the "great gaps in his mouth between his yellow teeth" (Dubliners 17).

Like all other quests and adventures in Dublin, the quest for the Pigeon House is gnomonic being incomplete and hopeless; it is destined to end in frustration. The disillusionment is on its way from the very beginning. The fact that "summer holidays [italics mine] were near at hand" (Dubliners 14) when the boy decides to break out of the school foreshadows the arrival of some "hollow", vacant days. There is no wonder why "The Sisters" begins, too, with the "vacation" time implying spiritual "vacancy" and "emptiness". Then, mysteriously, the night before their plan begins, the boy and his two fellow classmates are "all vaguely excited" (Dubliners 14). Why vaguely? Is it only because they feel a little anxious over their exciting short trip as young outlaws? Or is it ironic? Leo Dillon's failure to show next day can be read as another warning that something is missing in the illusion they pursuit, but they start their journey anyway. Watching the barges and the sailing vessels on the river, the boy "saw, or imagined, the geography which had been scantily close to [him] at school gradually taking substance under [his] eyes. School and home seemed to recede from [them] and their influences upon [them] seemed to wane (Dubliners 16). But, ironically, what is meant to wane and vanish gradually is indeed the "scantily close geography" which the boy fancies about. The adverb "scantily" (which means poorly and insufficiently) with its gnomonic quality insists that the adventurous freedom - the potentially missing corner of the boy's gnomonic life - will drift away for sure.

Having landed on the other side of the Liffey and noticed a Norwegian sailing ship, the boy examines "the foreign sailors to see had any of them green eyes for [he] had some confused notion..." (Dubliners 16). Gifford considers green eyes as "the eyes of a vigorous, youthful man, the ultimate adventurer" (39) or it may be the color of Odyssey's eyes the grand adventurer. But all the boy finds is blue, gray, and black (the fourth color is missing) except for a tall sailor "whose eyes could have been called green", and he only shouts "All right! All right!" (Dubliners 16) which sounds so commonplace and disappointing like the conversation the young boy overhears in the dark and deserted bazaar at the end of "Araby" (Dubliners 25), or Hynes' recitation of the poem he wrote for Parnell in "Ivy Day in Committee Room" (Dubliners 105-107). The Norwegian sailor becomes a dull sight for the boys soon, and the secret disappointment they feel accompanies them on through the sultry day along the squalid streets.

As the boys wander "through the squalid streets where the families of the fishermen live", they notice that the "day had grown sultry" (Dubliners 16). Joyce's choice of the alliterative "sultry" and "squalid" is so smart and serves the gnomonic purpose he follows here. "Sultry" can be defined as hot and humid, but it also means "airless" implying suffocation and lifelessness. "Squalid" means dirty and foul, but its resemblance to "square" and the connotative notion of the geometrically geographical entrapment of Dublin streets reveals the gnomonic existence of our young Dubliner. His mission is to be nipped in the bud, and eventually the young narrator surrenders to the impossibility of his short flight: "It was too late and we were too tired to carry out our project of visiting the Pigeon House" (Dubliners 16).

The sun-dial (shadow-making) function of gnomon is also at work here since the "sun [goes] in behind some clouds" (Dubliners 17) and symbolic light is going to be missing, gradually, in the life of our young exploring hero. Sidney Feshbach (1965) emphasizes the traditional association of sunset in the story with death saying " $[t]$ he passage of the sun reflects the predicament of the narrator in the universal order - the bright sun has agreed with his free life and the clouded sun serves to herald his imminent death" (83). The young boy is getting deprived of joy and blossoms of his youth, walking headlong into a life empty of aspiration, imaginative freedom, and natural education. Similarly, Herring (1987) states that the "price [the young boy] pays for such rude instruction will be a sense of humiliation that will not soon fade. [He has] sought light, positive images, and [has] been taught by negatives, shadows, the incomplete geometric shape instead of the whole one" (17). So, the young know-man is converted finally, due to the desperate circumstances, to such a helpless, joyless no-man.

As the day wanes, the journey toward the Pigeon House is diverted to the bank of the Dodder; but the darker omens prevail: Mahony is unhappy, clouds obscure the sun, and the boys' thoughts have turned jaded and their provisions to crumbs. But they have still got another thing coming. Like bits and pieces of clues in detective stories (that the young boy likes), such a collection of gnomonic diversions prepares the suspicious minds of the readers and the agitated 
emotions of the boys for the final dark revelation of their frustrating journey. But before the boys encounter the weird pervert, their physical entrapment seems to have become complete as they are seen surrounded by the unseen borders of the geometric field: "There was nobody but ourselves in the field" (Dubliners 17). After some silent minutes pass by, the boy sees "a man approaching from the far end of the field" (Dubliners 17). The significance of the rectangular field and a moving far corner of that is explicit. Moreover, carrying a stick, the man can be imagined as if he walks on three legs. Anyway, he soon diverts his own way, started from a far corner, and approaches the boys.

On the realistic level of the story, and as he appears to the boy, this poorly dressed old man would be an old pervert who is pleased with his sadistic concern with sensuality and violence. His behavior is strange enough and his questions are so unusually frank that the boy thinks, "[h]is attitude...struck me as strangely liberal in a man of his age" (Dubliners 18). The boy feels appalled by the way he talks, especially when he "shivered once or twice as if he feared something or felt a sudden chill" (Dubliners 18). But as far as gnomon is concerned, perversion cannot be a sufficient element to illustrate this old wandering man's character. To approach the old queer man, one has to approach an elaborate mystery. Although his mysterious presence is subject to many uncertain interpretations, the larger-than-life absence it evokes will certainly be worthy of note.

Undoubtedly, the old man appears to be "Death" personified. He does not fail to reveal the spiritual death and moral paralysis of a society determined to kill the sense of freedom and life which the youth have right to proclaim and enjoy. The man looks decaying: "He was shabbily dressed in a suit of greenish-black...He seemed to be fairly old for his mustache was ashen-grey" (Dubliners 17). He is the terminating force that puts an end to the probable progress of the boy's pilgrim to the Pigeon House. He begins talking about youth, excitement, and sex, but his conclusion is centered on only sadistic punishment and pain. Having been surprised by the old man's forgotten liberalism, the boy narrates that "[a] slap on the hand or a box on the ear was no good: what he wanted was to get a nice warm whipping" (Dubliners 19), and this horrifying monologue is continued. The man's mind seems to be trapped in an endless vicious cycle: "his mind was circling round and round in the same orbit. At times he spoke as if he were alluding to some fact that everybody knew" (Dubliners 18). And what is more distressing and factual than our final step, the end of our journey? Death. Sidney Feshbach (1965) gives his own account of the mysterious old man underlining the death symbolism he inspires

If we listen closely to what the man says we find that he speaks with increasing excitement about lost childhood (mutability), books and study (sobriety), and the play of sex and the punishment due the players (anti-carpe diem). The man, his words, and his manners, like the death's-head, bring Death's message, "Remember the end." (84)

And the end for the boy is nothing but the symbolic, unconscious death caused by the institutional and institutionalized paralysis and decay presented by a dying world.

The most mysterious and gnomonic moment, however, in the narration is when the old man leaves the boys for a couple of minutes walking away to the end of the field. What he really does in that far end of the field is uncertain and elliptical, but Mahony's reaction and the young boy's suspicious silence strengthen the idea of the perverted nature of the old man's unnamed conduct.

We remained silent when he had gone. After a silence of a few minutes I heard Mahony exclaim:

'I say! Look what he's doing!'

As I neither answered nor raised my eyes Mahony exclaimed again:

'I say...He's a queer old josser!' (Dubliners 18)

Whether the queer old man is urinating or masturbating, it is a moot point-we are not told that, and the young boy never informs us. Either way, the old man seems to be what we have known him to be, after all. But, quite ironically, we find "josser" to be a word that has come from a religious background. Both Gifford (1982: 40) and Tindall (1963: 18) are certain that "josser" is a Pidgin English for a worshipper of a "joss" or "god". Interestingly, the word resurfaces once again in Finnegans Wake:

all too many much illusions through photoprismic velamina of hueful panepiphanal world spectacurum of Lord Joss, the of which zoantholitic furniture, from mineral to through vegetal to animal, not appear to full up together fallen man than under but one photoreflection of the several iridals gradations of solar light...(611)

This passage describes Muta, an Irish druid, and Bishop Berkeley who are the defenders of the world of dream and the power of imagination, but fall victim to utility and fact-so much reminiscent of the main theme of "An Encounter". Obviously, the old pervert does not represent God, but what one may find instead of God or one who is supposed to be a link between people and God: a priest.

As mentioned before, Joyce does not always apply Euclid's gnomons to his story-telling style in Dubliners. He has even been influenced by Bruno's interpretation of gnomon. For Bruno, the gnomon becomes one more proof of the paradoxical doctrine of the fundamental identity of opposites or the coincidence of the contraries. That is to say, a figure that becomes enlarged to form an approximately maximum-sized version of its own will be identical in shape to the same figure that becomes diminished to the minimum-sized version of its own. So the maximum and the minimum come together in one existence resembling the shadows made by a sun-dial-all various in size by similar in shape. Now we realize the gnomonic analogy between the queer old man and the priest-teacher who are the very essence of the society that the young boy wished to escape. 
Ironically, the priest and the pervert, both, are associated with mystery and seriousness when the time comes for their business. Like a priest that is a vessel of the Christian mysteries and whispers enchantingly in a confession-box, the old man "lowered his voice and spoke mysteriously as if he were telling [the boys] something secret which he didn't wish others to overhear" (Dubliners 18). They both hold some secrets unknown to common people. Father Butler reprimands the boys for their reading stories of the Wild West and awakens the sense of guilt in them. He believes that someone who writes such stories is "some wretched fellow who writes these things for a drink", so he advises the boys strongly to "get at [their] work or..." (Dubliners 14). His incomplete gnomonic advice (threat, better to say) suggests punishment, obviously. Similarly, the old man alarms the boy by describing what awaits him if he gets involved in affection and love (romance). He says that "if a boy had a girl for a sweetheart and told lies about it then he would give him such a whipping as no boy ever got in this world...there was nothing in this world he would like so well as that" (Dubliners 19).

Consequently, as the priest awakens the sense of guilt, and the old man arouses that of atonement in the boy, they are, certainly, two sides of the religion in Ireland. The paralyzing counterparts, the priest and the pervert, interrupt the boy's quest, dry up his sea of romance, and submit his imagination to the diminishing clutches of paralyzing church. There is no wonder why almost all priestly figures in Dublin do not have the power to offer hope and salvation and are, as a matter of fact, far from being devout and faithful themselves. Their inherently spiritual vacancy must have been too vast for their so-called vocations. It is better to recall the opening paragraph of "An Encounter". The first sentence immediately introduces Joe Dillon who (despite his frequently church-going parents) is said to be the main source of the Wild West - utterly despised by Father Butler - and the conductor of the Indian battles for the kids. Physically threatening, Joe Dillon also "played too fiercely for [the young boy and other kids] who were younger and more timid" and every game was to end with his "war dance of victory" (Dubliners 13). Therefore, it is incredible for everyone to learn that Joe finally "had a vocation for the priesthood" (Dubliners 13), but it is nothing but the truth. The young savage is now a priest and Joyce's rich irony could not be more effective. These priests, therefore, can only teach frustration and despair to our young narrator so that he would become a fallen man, a no-man (gnomon), in a gnomonic land where the tides of darkness are creeping forever.

But Father Butler is not the only recognizable counterpart for the old pervert. The old man's age, physical appearance, and his mysterious behavior restore the image of Father Flynn in "The Sisters". They both wanted to teach the young boys. The old man was "shabbily dressed in a suit of greenish-black" (Dubliners 17); correspondingly, the "constant showers of snuff" had given Father Flynn's black garments "a green faded look" (Dubliners 8). Their analogous signs of spiritual paralysis and physical decay are also noticeable. The young boy wondered why Father Flynn's "lips were so moist with spittle" (Dubliners 7), and became dismayed when Father Flynn smiled and uncovered "his big discoloured teeth and let his tongue lie upon his lower lip" (Dubliners 8 ). The young boy in the second story, too, wonders why the old man "shivered once or twice as if he feared something or felt a sudden chill" (Dubliners 18). When the old man smiles, the boy notices that he has "great gaps in his mouth between his yellow teeth" (Dubliners 17). And finally, the decaying-priest figures (whose presence echoes hopelessly loss and absence) reassure the readers of the sad-but-true reality of Dublin life: Ambition, energy, free will, revolutionary zeal-these forces play no role and in a city and country where centuries of political and religious oppression had caused a general paralysis of mind and will. Transcendence came only through death and emigration.

\section{Conclusion}

What seems to be the most significant point here, beyond all these mystery-based analogies, is the larger-than-life gnomonic absence that the old pervert evokes. The fact that he is a counterpart for the inefficient, paralyzed and missing priests opens up a new dimension in my study of this story. In "The Sisters", Father Flynn is dead and missing and the church and his house echo his physical and spiritual absence. Father Butler, in "An Encounter", is exactly absent where he has to be present. As Leo Dillon is afraid they might encounter Father Butler on their way to the Pigeon House, Mahony asks, "very sensibly, what would Father Butler be doing out at the Pigeon House" (Dubliners 14). ). And if the Pigeon House is going to be empty of the priest, what other blessing presence can be there? Pigeon House, being the Dublin electricity and power station, represents symbolically the light and power - the metonymy for God. Not surprisingly, therefore, the pigeon, or dove, symbolizes the Holy Ghost also. The gnomonic integrity of Trinity is to be shattered with the present Son (the boy) and Holy Ghost and the absent third member: God (Father). What spiritual absence can be louder than this? The missing, absent father/priest and his suffocating hopeless absence that prevails afterwards are such familiar images in Dubliners. In "The Sisters", Father Flynn's absence echoes in his dark church and empty house; in "Araby", there is another dead priest whose once-occupied house is now invaded by the musty air; Eveline never finds out "the name of the priest whose yellowing photograph hung on the wall" (Dubliners 27); and Gabriel Conroy's priest brother, Constantine, is a symbolically absent guest in the Christmas party in "The Dead".

Expressively, therefore, the pervert seems to be an ironically suitable replacement for the fathers of Ireland's paralyzing Christianity. Frustration is the end of all such youth quests in the spiritual wasteland of Dublin. The price that all such young boys pay for their self-willed instructions will be a sense of humiliation that remains with them for years. The protagonists in all these stories of childhood and maturity meant to seek light and positive images, but were eventually haunted by the distorting shadows and gnomons of the paralysis-ridden Dublin; incompletion and loss mark their destiny; incompletion and loss mark their destiny. 


\section{References}

Borg, R. (2010). Mirrored Disjunctions: On a Deleuzo-Joycean Theory of the Image. Journal of Modern Literature, 33(2), 131-148.

Bulson, E. (2006). The Cambridge Introduction to James Joyce. Cambridge: Cambridge University Press.

Daiches, D. (1968). Dubliners. In Peter K. Garrett (Ed.), Twentieth Century Interpretations of Dubliners (27-37) Englewood Cliffs: Prentice-Hall, Inc.

Eide, M. (2004). Ethical Joyce. Cambridge: Cambridge University Press.

Feshbach, S. (1965). Death in “An Encounter”. James Joyce Quarterly, 2 (2), 82-89.

Gifford, D. (1982). Joyce Annotated. California: University of California Press.

Gordon, J. (1995). Dubliners and the Art of Losing. Studies in Modern Fiction. Retrieved from http://findarticles.com/p/articles/mi_m2455/is_n3_v32/ai_19517926.

Herring, P. F. (1987). Joyce's Uncertainty Principle. Princeton: Princeton University Press.

Joyce, J. (1992). A Portrait of the Artist as a Young Man. New York: Gramercy Books.

Joyce, J. (1914). Dubliners. New York: Gramercy Books.

Joyce, J. (1964). Finnegans Wake. London: Faber and Faber.

Magalaner, M. \& Kain, R. M. (1957). Joyce: The Man, the Work, The Reputation. London: John Calder.

Simon, R. (1821). The Elements of Euclid. Philadelphia: Robert and Thomas Desilver.

Spinks, L. (2009). James Joyce: A Critical Guide. Edinburgh: Edinburgh University Press.

Tindall, W. Y. (1963). A Reader's Guide to James Joyce. London: Thames and Hudson.

Weir, D. (1991). Gnomon is an island: Euclid and Bruno in Joyce's Narrative Practice. James Joyce Quarterly, 28 (2), 343-360. 